\title{
Post-harvest residues of narrow-leafed lupin/oat mixtures as a source of biological nitrogen for hybrid winter rye
}

\author{
Anna Płaza, Barbara Gąsiorowska, Emilia Rzążewska \\ Siedlce University of Natural Sciences and Humanities, Faculty of Agrobioengineering and Animal \\ Husbandry, Institute of Agriculture and Horticulture, Siedlce, Poland
}

\begin{abstract}
Post-harvest residues of narrow-leafed lupin/oat mixtures are a valuable source of biological nitrogen for the following crop plants, including winter cereals. Hybrid winter rye, which is increasingly popular in Germany and Poland, positively responds to cultivation at good sites. The objective of the research was to determine the effect of the biomass of the post-harvest residues of narrow-leafed lupin, oat and their mixtures on yield performance and amount of nitrogen accumulated in hybrid winter rye grain. The following two factors were examined in an experiment: factor I - forecrop mixtures: narrow-leafed lupin - pure stand 100\%, oat - pure stand $100 \%$, narrow-leafed lupin $75 \%$ + oat $25 \%$, narrowleafed lupin $50 \%+$ oat $50 \%$, narrow-leafed lupin $25 \%+$ oat $75 \%$; factor II - forecrop harvest date: the stage of narrow-leafed lupin flowering, the stage of narrow-leafed lupin flat green pod. The results demonstrated that oat and narrow-leafed lupin/oat mixtures containing $25+75 \%$ and $50+50 \%$ of the respective components and harvested at the stage of narrow-leafed lupin flat green pod supplied the greatest amount of post-harvest residue biomass, and narrow-leafed lupin harvested at the aforementioned stage accumulated the most nitrogen. Hybrid winter rye following the forecrop of narrow-leafed lupin/oat mixture containing $50+50 \%$ of the respective components and harvested at the stage of narrowleafed lupin flat green pod produced the highest grain yield.
\end{abstract}

Correspondence: Emilia Rzążewska, Siedlce University of Natural Sciences and Humanities, Faculty of Agrobioengineering and Animal Husbandry, Institute of Agriculture and Horticulture, 14 Prusa Steet, 08110 Siedlce, Poland.

Tel.: +48256431237. E-mail: emilia.rzazewska@uph.edu.pl

Key words: Forecrop; narrow-leafed lupin/oat mixtures; hybrid winter rye; yield; nitrogen content.

Received for publication: 17 June 2019.

Revision received: 13 March 2020.

Accepted for publication: 13 March 2020.

(C) Copyright: the Author(s), 2020

Licensee PAGEPress, Italy

Italian Journal of Agronomy 2020; 15:1503

doi:10.4081/ija.2020.1503

This article is distributed under the terms of the Creative Commons Attribution Noncommercial License (by-nc 4.0) which permits any noncommercial use, distribution, and reproduction in any medium, provided the original author(s) and source are credited.

\section{Introduction}

Maincrop leguminous plants are a valuable animal feed, and their post-harvest residues may support nitrogen biological stabilisation, and are more environmentally-friendly than mineral fertilisers (Jensen and Hauggaard-Nielsen, 2003; Herridge et al., 2008). However studies by Mayer et al. (2003), Tripolskaja and Sidlauskas (2010) as well as Nemeikšiene et al. (2010) demonstrated that legume biomass applied in winter wheat cultivation may lead to mineral nitrogen leaching during the autumn-winterearly spring period due to rapid mineralisation of nitrogen-rich biomass. To prevent this negative phenomenon, legume/cereal or legume/grass mixtures should be recommended for cultivation. Such biomass is characterised by a wider $\mathrm{C}: \mathrm{N}$ ratio, which slows the mineralisation of incorporated post-harvest residues compared with legumes grown in pure stand. As a result, there is a more regular supply of biological nitrogen for the following crop plant during the whole growing season, which prevents $\mathrm{N}$ leaching into deeper soil strata, and takes care of the soil environment (Lewan, 1994; Arlauskiene and Maiksteniene, 2008; Nemeikšiene et al., 2010). There have been many European studies in which clover was strip-sown into cereals in order to develop a double-cropping system which makes it possible to reduce mineral nitrogen fertiliser reliance (Sarunaite et al., 2013).

It seems that hybrid winter rye will positively respond to cultivation at good sites. Poland and Germany are leaders of hybrid winter rye production and new technologies are developed in both the countries to intensify the production of this crop. F1 cultivars produce superior yields compared with population cultivars (Peter, 2005). However, there is a lack of research on the cultivation of this species after a forecrop of legume/cereal mixtures. Hence the need arises to conduct such studies. The aim of the research reported here was to determine the influence of post-harvest residue biomass of narrow-leafed lupin, oat and their mixtures on yield performance and amount of nitrogen accumulated in hybrid winter rye grain.

\section{Materials and methods}

A field experiment was conducted in the years 2010-2012 at

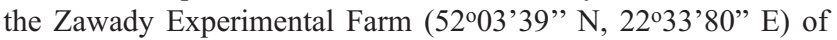
Siedlce University of Natural Sciences and Humanities. The experimental soil was Stagnic Luvisol, its reaction was neutral and it contain average amounts of available phosphorus, potassium and magnesium. Humus content was $1.38 \%$. The experiment was a split-block arrangement with three replicates. Two factors were investigated: I - the forecrop of narrow-leafed lupin grown in pure stand $100 \%$, oat grown in pure stand $100 \%$, narrow-leafed lupin $75 \%+$ oat $25 \%$, narrow-leafed lupin $50 \%+$ oat $50 \%$, narrow- 
leafed lupin $25 \%$ + oat $75 \%$; II - forecrop harvest date: the stage of narrow-leafed lupin flowering, the stage of narrow-leafed lupin flat green pod. The seeding density were as follows: narrow-leafed lupin 312 seeds $\mathrm{m}^{-2}$, oat 196 grains $\mathrm{m}^{-2}$, narrow-leafed lupin 234 seeds $\mathrm{m}^{-2}+$ oat 49 grains $\mathrm{m}^{-2}$, narrow-leafed lupin 156 seeds $\mathrm{m}^{-2}$ + oat 98 grains $\mathrm{m}^{-2}$, narrow-leafed lupin 78 seeds $\mathrm{m}^{-2}+$ oat 147 grains $\mathrm{m}^{-2}$. Winter rye preceded the mixtures in all the study years. Phosphorus and potassium fertilisers were applied in autumn at the rates expressed on an elemental base related to soil chemical composition, that is $35.2 \mathrm{~kg} \cdot \mathrm{ha}^{-1} \mathrm{P}$ and $99.6 \mathrm{~kg} \cdot \mathrm{ha}^{-1} \mathrm{~K}$.

In spring, seed sowing was preceded by nitrogen application at the rate of $30 \mathrm{~kg} \cdot \mathrm{ha}^{-1}$, $\mathrm{N}$ being applied to all the plots excluding narrow-leafed lupin grown in pure stand. Additional nitrogen inputs of 50 and $30 \mathrm{~kg} \cdot \mathrm{ha}^{-1}$ were applied to, respectively, oat and narrow-leafed lupin/oat mixtures at the stage of stem elongation. Narrow-leafed lupin cv. Zeus and oat cv. Zuch were seeded in early April as described for factor I. The plants were harvested in late June (stage of narrow-leafed lupin flowering) and early July (stage of narrow-leafed lupin flat green pod). After the forecrop harvest, post-harvest residues of narrow-leafed lupin/oat mixtures were collected from an area of $1 \mathrm{~m}^{2}$ and to the depth of $30 \mathrm{~cm}$ in each plot in order to determine dry matter yield. The post-harvest residue dry matter was used to determine total nitrogen content by Kjeldahl method.

Hybrid winter rye cv. Brasetto F1 was sown at the rate of 98 grains $\mathrm{m}^{-2}$ in mid-September. Phosphorus and potassium fertilisers, were applied pre-plant at the rates adjusted to soil availability, that is $60 \mathrm{~kg} \cdot \mathrm{ha}^{-1} \mathrm{P}$ and $90 \mathrm{~kg} \cdot \mathrm{ha}^{-1} \mathrm{~K}$. Nitrogen fertiliser amount was split into two rates of 40 and $60 \mathrm{~kg} \cdot \mathrm{ha}^{-1}$ applied, respectively, after the cereal resumed growth in the spring, and at the stage of stem elongation. Hybrid winter rye was harvested in late July. Grain yield was measured in each plot and its average samples were collected to determine total nitrogen by means of Kjeldahl method. Moreover, thousand grain weight was determined.

The tested characteristics were subjected to analysis of variance in a split-block design following the model: $\mathrm{y}_{\mathrm{ijl}}=\mathrm{n}+\mathrm{a}_{\mathrm{i}}+\mathrm{g}_{\mathrm{i}}+$ $\mathrm{e}_{\mathrm{ij}}{ }^{(1)}+\mathrm{b}_{1}+\mathrm{e}_{\mathrm{jl}}(2)+\mathrm{ab}_{\mathrm{il}}+\mathrm{e}_{\mathrm{ijl}}(3)$, where $\mathrm{a}=1,2 ; \mathrm{b}=1,2 \ldots 5 ; \mathrm{n}=1,2$, 3 (number of replicates); $y_{\mathrm{ijl}}$ - value of the examined characteristic; $a_{i}$ - effect of the $i$-th level of factor $A ; g_{j}$ - effect of replicates (blocks); $\mathrm{e}_{\mathrm{ij}}^{(1)}$ - error 1 associated with the interaction: factor $\mathrm{Ax}$ replicates; $b_{1}$ - effect of the 1-th level of factor $B$; $e_{j 1}{ }^{(2)}$ - error 2 associated with the interaction: factor $\mathrm{B} \times$ replicates; $\mathrm{ab}_{\mathrm{il}}$ - affect of the interaction: A x B; $\mathrm{e}_{\mathrm{ijl}}{ }^{(3)}$ - random error. Comparison of means for significant sources of variation was achieved by means of Tukey's test at the significance level of $\mathrm{P} \leq 0.05$. All the calculations were performed in STATISTICA, version 12.0, and MS Excel.

\section{Results}

The amount of post-harvest residues supplied by narrow-leafed lupin/oat mixtures was significantly affected by the experimental factors and their interaction (Table 1). The greatest amount of the residues was produced by oat and narrow-leafed/oat mixtures containing $25+75 \%$ and $50+50 \%$ of the respective components. Only the $75+25 \%$ mixture and narrow-leafed lupin produced the lowest quantity of the residues. Harvest date had a significant effect on the amount of post-harvest residues supplied by narrowleafed lupin/oat mixtures. More residues were associated with narrow-leafed lupin/oat mixtures harvested at the stage of narrowleafed lupin flat green pod compared with the narrow-leafed lupin flowering stage. An interaction was confirmed, which indicated that more post-harvest residues were supplied by oat and narrowleafed lupin/oat mixtures containing $25+75 \%$ and $50+50 \%$ of the respective components harvested at the stage of flat green pod compared with narrow-leafed lupin grown in pure stand or mixed with oat and harvested at the flowering stage.

Statistical analysis demonstrated a significant effect of the experimental factors and their interaction on the amount of nitrogen supplied to soil with the incorporated biomass of post-harvest residues of narrow-leafed lupin/oat mixtures (Table 2). The greatest nitrogen amount was supplied by narrow-leafed lupin and narrow-leafed lupin/oat mixtures containing $75+25 \%$ and $50+50 \%$ of the respective components. The residues of oat and narrowleafed lupin/oat mixture containing $25+75 \%$ of the respective components supplied the soil with the lowest amount of nitrogen. Harvest date significantly influenced the amount of nitrogen supplied with the biomass of legume/cereal post-harvest residues entering the soil. More nitrogen was supplied by residues of narrow-leafed lupin/oat mixtures harvested at the stage of narrowleafed flat green pod compared with the flowering stage. An interaction was confirmed: the greatest amount of nitrogen was supplied to the soil with the post-harvest residues of narrow-leafed

Table 1. Amount of dry matter of forecrop residues of narrow-leafed lupin/oats mixtures (means across 2010-2011), tha $\mathrm{a}^{-1}$.

\begin{tabular}{|c|c|c|c|}
\hline \multirow[t]{2}{*}{ Forecrop - mixtures I } & \multicolumn{2}{|c|}{ Forecrop harvest date II } & \multirow[t]{2}{*}{ Means } \\
\hline & $\begin{array}{c}\text { Stage of narrow-leafed lupin } \\
\text { flowering }\end{array}$ & $\begin{array}{l}\text { Stage of narrow-leafed lupin } \\
\text { flat green pod }\end{array}$ & \\
\hline Narrow-leafed lupin - pure stand 100\% & 4.83 & 5.72 & 5.28 \\
\hline Oat - pure stand $100 \%$ & 5.66 & 6.93 & 6.30 \\
\hline Narrow-leafed lupin $75 \%+$ oat $25 \%$ & 5.04 & 5.97 & 5.51 \\
\hline Narrow-leafed lupin 50\% + oat 50\% & 5.37 & 6.48 & 5.93 \\
\hline Narrow-leafed lupin $25 \%+$ oat $75 \%$ & 5.51 & 6.69 & 6.10 \\
\hline Means & 5.28 & 6.36 & - \\
\hline ANOVA & \multicolumn{2}{|c|}{ P-value } & $\mathrm{HSD}_{0.05}$ \\
\hline Forecrop-mixture I & \multicolumn{2}{|c|}{$<0.001$} & 0.69 \\
\hline Forecrop harvest date II & \multicolumn{2}{|c|}{$<0.001$} & 0.32 \\
\hline Interaction: IxII & \multicolumn{2}{|c|}{$<0.001$} & 0.78 \\
\hline
\end{tabular}


lupin harvested at the flat green pod stage, and by narrow-leafed lupin/oat mixtures containing $75+25 \%$ and $50+50 \%$ of the respective components and harvested at the aforementioned growth stage. The lowest nitrogen supply was associated with oat residues harvested at the stage of narrow-leafed lupin flowering.

Hybrid winter rye grain yield was significantly influenced by the experimental factors and their interaction (Table 3). The highest grain yield was recorded in plots where the post-harvest residues of narrow-leafed lupin/oat mixture containing $50+50 \%$ of the respective components had been incorporated into the soil. Hybrid winter rye grain yields were lower following an incorporation of post-harvest residues of narrow-leafed lupin/oat mixture containing $75+25 \%$ of the respective components, and narrowleafed lupin grown in pure stand, the yields reaching a satisfactory level. An incorporation of oat residues as well as residues of narrow-leafed lupin/oat mixture containing $25+75 \%$ of the respective components contributed to the poorest yield performance of hybrid winter rye. Forecrop harvest date had a significant effect on the grain yield of hybrid winter rye, the yield being higher when narrow-leafed lupin mixed with oat was harvested at the flat pod stage than flowering stage. An interaction was confirmed, which indicated that the highest winter rye grain yield was produced after an incorporation of narrow-leafed lupin/oat mixture containing 50 $+50 \%$ of the respective components harvested at the stage of nar- row-leafed lupin flat green pod, it being the lowest after oat harvested at the narrow-leafed lupin flowering stage.

Statistical analysis revealed a significant effect of the experimental factors and their interaction on the thousand grain weight of hybrid winter rye (Table 4). The highest thousand grain weight was recorded for hybrid winter rye following the forecrop of narrowleafed lupin/oat mixtures containing $50+50 \%$ and $75+25 \%$ of the respective components. When rye followed narrow-leafed lupin, thousand grain weight was the same as the value for rye following narrow-leafed lupin/oat mixture containing $75+25 \%$ of the respective components, it being significantly lower in the remaining experimental units. Harvest date had a significant impact on the thousand grain weight of hybrid winter rye. The weight was significantly higher for rye following narrow-leafed lupin/oat mixtures harvested at the stage of narrow-leafed lupin flat green pod compared with the flowering stage. An interaction was confirmed: the highest thousand grain weight was determined for hybrid winter rye following narrow-leafed lupin/oat mixtures containing $50+$ $50 \%$ and $75+25 \%$ of the respective components harvested at the stage of narrow-leafed lupin flat green pod, and the mixture composed of $50 \%$ legume $+50 \%$ cereal component and harvested at the stage of narrow-leafed lupin flowering, the weight being the lowest after oat regardless of the harvest date.

The amount of total nitrogen accumulated in the grain of

Table 2. Nitrogen amount introduced into the soil with incorporated residue biomass of narrow-leafed lupin/oat mixtures (means across 2010-2011), $\mathrm{kg} \cdot \mathrm{ha}^{-1}$.

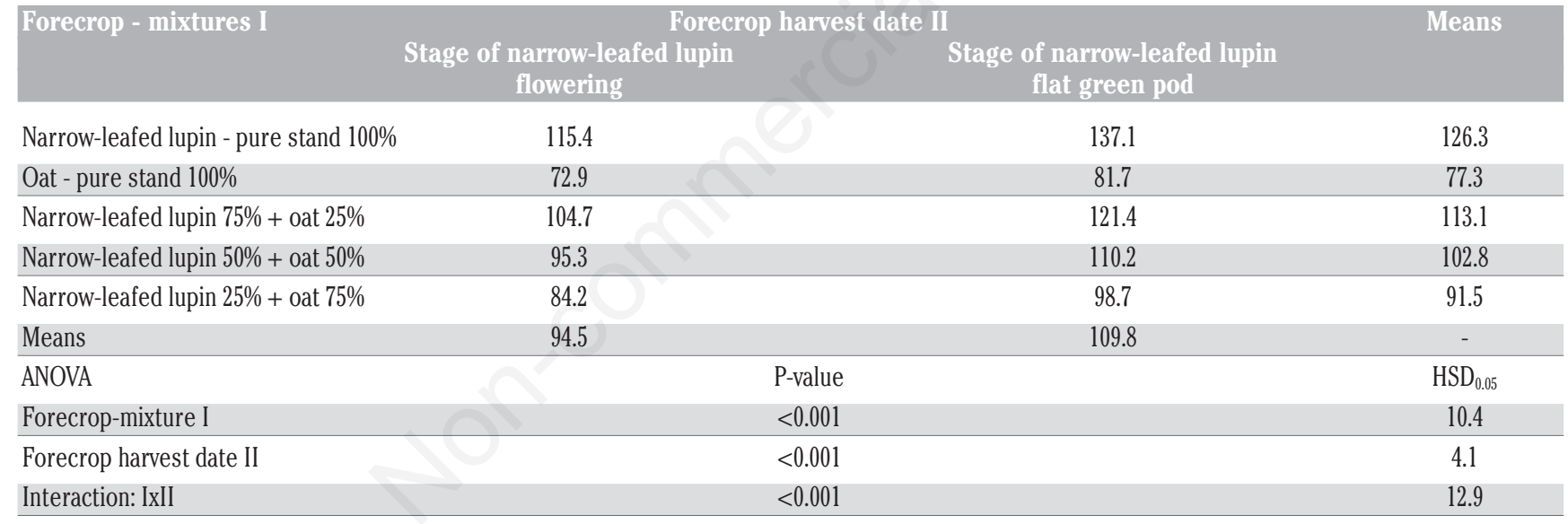

Table 3. Grain yield of hybrid winter rye (means across 2011-2012), th' ha ${ }^{-1}$.

\begin{tabular}{|c|c|c|c|}
\hline \multirow[t]{2}{*}{ Forecrop - mixtures I } & \multicolumn{2}{|c|}{ Forecrop harvest date II } & \multirow[t]{2}{*}{ Means } \\
\hline & $\begin{array}{c}\text { Stage of narrow-leafed lupin } \\
\text { flowering }\end{array}$ & $\begin{array}{c}\text { Stage of narrow-leafed lupin } \\
\text { flat green pod }\end{array}$ & \\
\hline Narrow-leafed lupin - pure stand 100\% & 9.06 & 9.87 & 9.47 \\
\hline Oat - pure stand $100 \%$ & 8.04 & 8.75 & 8.40 \\
\hline Narrow-leafed lupin $75 \%+$ oat $25 \%$ & 9.85 & 10.61 & 10.23 \\
\hline Narrow-leafed lupin $50 \%+$ oat $50 \%$ & 10.74 & 11.90 & 11.32 \\
\hline Narrow-leafed lupin $25 \%+$ oat $75 \%$ & 8.86 & 9.57 & 9.22 \\
\hline Means & 9.31 & 10.14 & - \\
\hline ANOVA & & & $\mathrm{HSD}_{0.05}$ \\
\hline Forecrop-mixture I & & & 0.51 \\
\hline Forecrop harvest date II & & & 0.28 \\
\hline Interaction: IxII & & & 0.59 \\
\hline
\end{tabular}


hybrid winter rye was significantly affected by the experimental factors and their interaction (Table 5). The highest amount was accumulated by the grain of rye following narrow-leafed lupin/oat mixtures containing $50+50 \%$ and $75+25 \%$ of the respective components. Total nitrogen accumulation following narrow-leafed lupin differ insignificant from the value recorded for hybrid winter rye following narrow-leafed lupin/oat mixture containing $75+$ $25 \%$ of the respective components, it being significantly lower in the remaining plots. Harvest date had a significant effect of the amount of total nitrogen in hybrid winter rye grain. More total nitrogen was accumulated in the grain of rye following narrowleafed lupin/oat mixtures harvested at the stage of narrow-leafed lupin flat green pod compared with the flowering stage. A significant interaction was confirmed: the highest amount of total nitrogen was accumulated by hybrid winter rye grown after the forecrop of narrow-leafed lupin/oat mixture containing $50+50 \%$ of the respective components and harvested at both the developmental stages examined in the study, it being the lowest after oat regardless of the harvest date.

\section{Discussion}

Post-harvest residues of legumes and their mixtures with cere- als or grasses are a valuable source of biological nitrogen for the following crop plants (Bergvist, 2003). Modern agriculture aims at limiting mineral nitrogen inputs to the advantage of biological nitrogen which does not pose a threat to the environment (Hauggaard-Nielsen et al., 2012). The present study demonstrated that the post-harvest residues of narrow-leafed lupin/oat mixtures grown for green matter are a valuable biological nitrogen source for crop plants. Also Thorsted et al. (2006) as well as Arlauskiene and Maiksteniene (2008) found that, due to biological transformation, the incorporated biomass becomes a nitrogen source for crop plants in the following year. In the experiment reported here, the highest amount of post-harvest residues was supplied by oat as well as the narrow-leafed lupin/oat mixture containing $25+75 \%$ of the respective components. Buraczyńska et al. (2011), who grown field pea, spring triticale and their mixtures, reported that the greatest amount of post-harvest residues was supplied by spring triticale grown in pure stand and mixed with field pea $(25+$ $75 \%$ of the respective components). High biomass production of grass and cereal biomass has been reported by Watson et al. (2002), Arlauskiene and Maiksteriene (2008), Nemeikšiene et al. (2010) as well as Sarunaite et al. (2013). In the present study, the post-harvest residues of narrow-leafed lupin grown in pure stand supplied the soil with the lowest biomass amount. Also research by Bergvist (2003) and Panagiotis (2015) demonstrated that, com-

Table 4. Thousand grain weight of hybrid winter rye (means across 2011-2012).

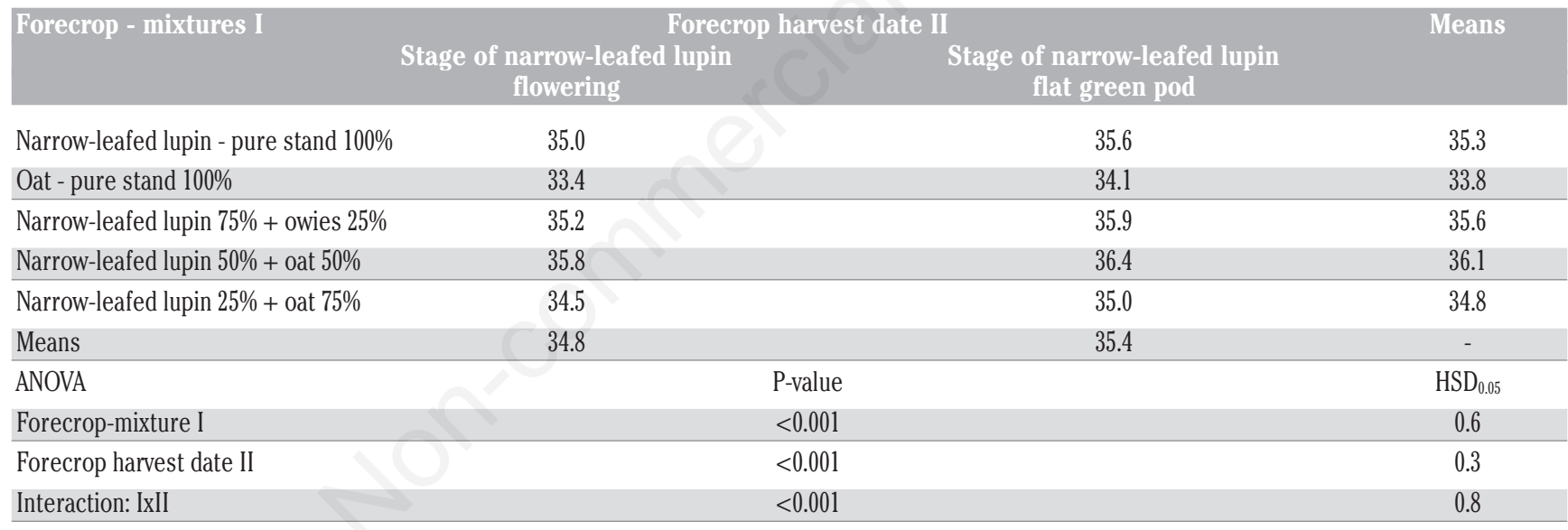

Table 5. Total nitrogen accumulated in the grain of hybrid winter rye (means across 2011-2012), $\mathrm{kg}^{\cdot h a^{-1}}$.

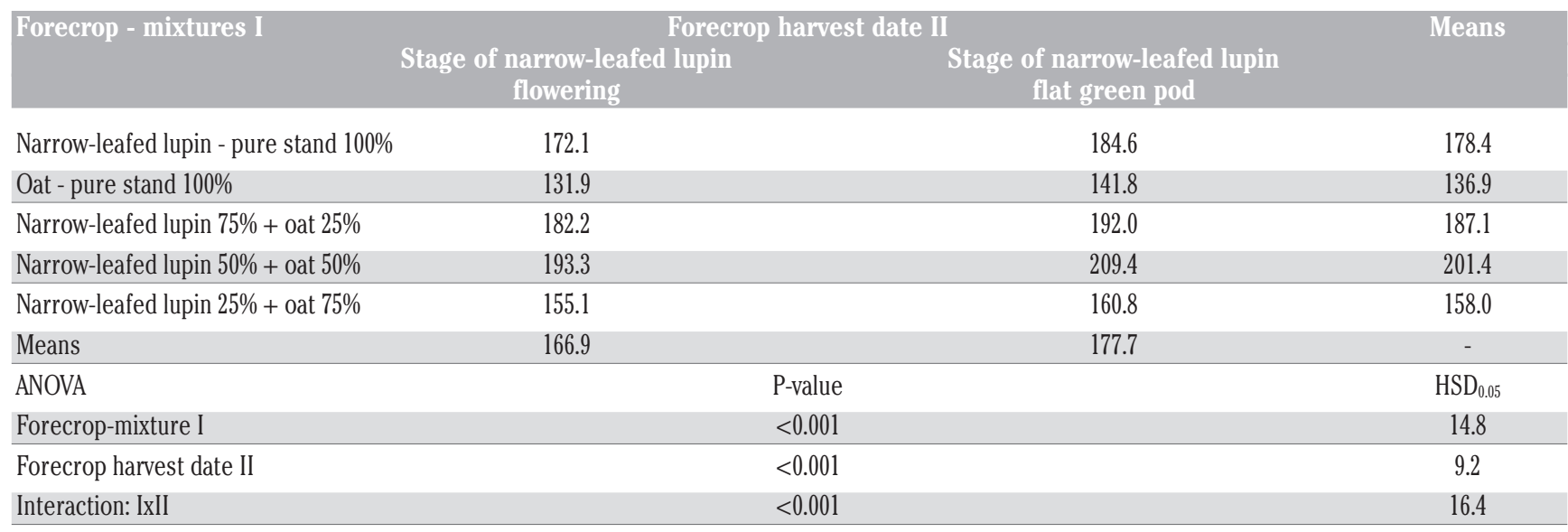


pared with cereals or grasses, legumes supply the lowest amount of biomass, which is due to the fact that the rooting system of leguminous plants is not as well developed at that of grasses. In the experiment reported here, harvest date significantly affected the amount of dry matter supplied with the post-harvest residues of narrow-leafed lupin mixed with oat. Significantly more post-harvest residues were supplied by narrow-leafed lupin/oat mixtures harvested at the stage of narrow-leafed lupin flat green pod compared with the flowering stage. A possible explanation is that plants harvested at a later date have more time to produce more root matter, which translates into a greater amount of biomass in the form of post-harvest residues.

The post-harvest residues of legumes and their mixtures with cereals are a valuable source of biological nitrogen for the following plants (Buraczyńska et al., 2011). In the present work, the highest nitrogen amount was introduced into the soil with the postharvest residues of narrow-leafed lupine grown in pure stand, which is consistent with findings reported by Bergvist (2003), Thorsed et al. (2006), Sarunaite et al. (2013) and Panagiotis (2015). It should be emphasised that residues of legume/cereal mixtures are a source of a substantial nitrogen amount (Lemola et al., 2000; Kănkănen and Eriksson, 2007; Kramberger et al., 2009; Buraczyńska et al., 2011). In the present study, residues of the narrow-leafed lupin/oat mixture containing $75+25 \%$ of the respective components proved to be the richest source of total nitrogen. The performance of oat residues was the worst in this respect, which was due to the fact that non-legumes contain less total nitrogen and so their supply of this nutrient for the following crop is lower, the finding confirmed by Kănkănen and Eriksson (2007) who demonstrated that grasses supplied the following crop with the lowest nitrogen amount. In the research reported here, the harvest date of narrow-leafed lupin/oat mixtures significantly influenced total nitrogen amount supplied to the soil with post-harvest residues. More nitrogen was supplied by narrow-leafed lupin/oat mixtures harvested at the stage of narrow-leafed lupin flat green pod compared with the flowering stage. The possible explanation is the fact that plants harvested earlier in the growing season contain more nitrogen but its supply is lower because less biomass of post-harvest residues has been produced compared with plants harvested at a later date, which is consistent with findings reported by Utomo et al. (1992), Clark et al. (1998) and Mechri et al. (2016).

German research demonstrated that hybrid winter rye cultivars produce superior yields compared with population ones (Miedaner et al., 2014; Laidig et al., 2017). However, the hybrid cultivars perform better when grown at good sites. In the study reported here, post-harvest residues of narrow-leafed lupin mixed with oat positively affected the grain yield of hybrid winter rye, the highest yield performance being observed following an incorporation of the post-harvest residues of the narrow-leafed lupin/oat mixture containing $50+50 \%$ of the respective components. A high rye grain yield was also obtained after the $75+25 \%$ mixture when it was harvested at the stage of narrow-leafed lupin flat green pod. Buraczyńska et al. (2011) reported the highest winter wheat grain yield following an incorporation of post-harvest residues combined with straw of a spring triticale/field pea mixture containing $25+75 \%$ of the respective components, and after the ploughing down of field pea residues and straw. Undersown legumes in studies by Kănkănen et al. (2001), Kănkănen and Eriksson (2007) as well as Nemeikšiene et al. (2010) positively affected cereal grain yield. In the work reported here, the grain yield of hybrid winter rye was the lowest after an incorporation of oat residues.
Also Buraczyńska et al. (2011) found that the post-harvest residues of spring triticale harvested for grain contributed to a decline in winter wheat grain yield compared with field pea residues. Kănkănen and Eriksson (2007) as well as Nemeikšience et al. (2010) obtained lower cereal grain yields following undersown grasses. It ought to be explained by the fact that legumes and their mixtures with cereals or grasses have a narrower $\mathrm{C}: \mathrm{N}$ ratio, which leads to a more rapid decomposition of the incorporated biomass and, as a result, release more nitrogen available for the following crop which can produce higher yields. In the experiment reported here, the harvest date of narrow-leafed lupin/oat mixtures significantly affected the yield performance of hybrid winter rye. A higher grain yield was recorded following an incorporation of the residues of narrow-leafed lupin mixed with oat and harvested at the stage of narrow-leafed lupin flat green pod compared with the flowering stage. This is possibly due to the fact that narrowleafed lupin/oat residues incorporated at an earlier developmental stage mineralise more rapidly, and the following plant is unable to fully utilise the released mineral nitrogen which is lost due to leaching into deeper soil strata, and pollutes the soil environment. Better results can be obtained after ploughing down of legume/cereal post-harvest residues at a later developmental stage, that is at the stage of legume flat green pod.

In the experiment reported here, the thousand grain yield of hybrid winter rye was the highest when the cereal was grown at a good site, that is after narrow-leafed lupin/oat mixtures containing $50+50 \%$ and $75+25 \%$ of the respective components. Also Buraczyńska et al. (2011) found the highest thousand grain weight of winter wheat, and superior grain yield as well, when the cereal followed a spring triticale/field pea mixture containing $25+75 \%$ of the respective components. It was due to the fact that the good site which was rich in biological nitrogen positively affected the yield performance and grain fill of the winter cereal.

The present work demonstrated that grain of hybrid winter rye takes up various nitrogen amounts depending on the forecrop. The greatest amount of total nitrogen was determined in the grain of winter rye following the spring triticale/field pea mixture containing $75+25 \%$ of the respective components, which agrees with findings reported by Buraczyńska et al. (2011) who found that the highest nitrogen amount in the grain of winter wheat following field pea grown for seed and a spring triticale/field pea mixture containing $25+75 \%$ of the respective components. A positive effect of legumes on nitrogen uptake by cereal yield has also been reported by Kănkănen and Eriksson (2007), Herridge et al. (2008), Nemeikšiene et al. (2010) and Hauggard-Nielsen et al. (2012). This follows from the fact that post-harvest residues of legumes contain much nitrogen compared with non-leguminous plants, the nitrogen being made available for the following crop after mineralisation. The work reported here demonstrated that narrow-leafed lupin/oat mixtures containing $75+25 \%$ and $50+50 \%$ of the respective components positively affected nitrogen accumulation in hybrid winter rye grain. More total nitrogen was determined in the grain after hybrid winter rye followed narrow-leafed lupin mixed with oat and harvested at the flat pod stage compared with the flowering stage. This can be explained by the fact that post-harvest residues of narrow-leafed lupin/oat mixtures accumulated more nitrogen at the flat pod stage than the flowering stage of narrow-leafed lupin. As a result, the cereal recovers the nitrogen fixed by legumes from the air, which reduces the risk of $\mathrm{N}$ leaching (Nykänen et al., 2009; Nemeikšiene et al., 2010). 


\section{Conclusions}

Oat and narrow-leafed lupin/oat mixtures containing $25+75 \%$ and $50+50 \%$ of the respective components harvested at the stage of narrow-leafed lupin flat green pod supplied the greatest amount of post-harvest residue biomass, and narrow-leafed lupin harvested at this stage accumulated the most nitrogen in its residues.

Cultivation of hybrid winter rye following the narrow-leafed lupin/oat mixture containing $50+50 \%$ of the respective components and harvested at the stage of narrow-leafed lupin flat green pod contributed to the best grain yield performance of the cereal.

The greatest thousand grain yield and the highest amount of total nitrogen in the grain of hybrid winter rye were recorded following narrow-leafed lupin mixed with oat at the respective component proportions of $50+50 \%$, regardless of the harvest date.

\section{References}

Arlauskiene A, Maiksteniene S. 2008. The effects of cover crops and straw on soil mineral nitrogen dynamics and losses from arable land. Agronomijas Věstis. Latvian J. Agron. 11:195201.

Bergkvist G, 2003. Effect of white clover and nitrogen availability on the grain yield of winter wheat in a three-season intercropping system. Acta Agr. Scand. B-S P. 53:97-109.

Buraczyńska D, Ceglarek F, Gąsiorowska B, ZaniewiczBajkowska A, Płaza A, 2011. Cultivation of wheat following pea and triticale/pea mixtures increases yields and nitrogen content. Acta Agr. Scand. B-S P. 61:622-32.

Clark MS, Howarth WR, Shennan C, Scow KM, 1998. Changes in soil chemical properties resulting from organic and low-input farming practices. Agron. J. 90:662-71.

Crews TE, Peoples MB, 2005. Can the synchrony of nitrogen supply and crop demand be improved in legume and fertilizerbased agroecosystem? Nutr Cycl Agroecosys. 72:101-20.

Hauggaard-Nielsen H, Mundus S, Jensen ES, 2012. Grass-clover undersowing affects nitrogen dynamics in a grain legume-cereal arable cropping system. Field Crop. Res. 136:23-31.

Herridge DF, Peoples MB, Boddey RM, 2008. Global inputs of biological nitrogen fixation in agricultural system. Plant Soil. 311:1-18.

Jensen ES, Hauggaard-Nielsen H, 2003. How can increased use of biological $\mathrm{N}_{2}$ fixation in agriculture benefit the environment? Plant Soil. 252:177-186.

Känkänen H, Eriksson C, 2007. Effects of undersown crops on soil mineral $\mathrm{N}$ and grain yield of spring barley. Eur. J. Agron. 27:25-34.

Känkänen H, Eriksson C, Räkköläinen M, Vuorien M, 2001. A Effect of annually repeated undersowing on cereal grain yields. Agr. Food Sci. Finland. 10:197-208.

Kumar K, Goh KM, 2002. Management practices of antecedent leguminous and non-leguminous crop residues in relation to winter wheat yields, nitrogen uptake, soil nitrogen mineralization and simple nitrogen balance. Eur. J. Agron. 16:295-308.

Kramberger B, Gselman A, Janzekovic M, Kaligaric M, Bracko B, 2009. Effects of cover crops on soil mineral nitrogen and on yield and nitrogen content of maize. Eur. J. Agron. 31:103-9.

Laidig F, Piepho HP, Rentel D, Drobek T, Meyer U, Huesken A, 2017. Breeding progress, variation, and correlation of grain and quality traits in winter rye hybrid and population varieties and national on-farm progress in Germany over 26 years. Theor. Appl. Genet. 130:981-98.

Lemola R, Turtola E, Erikson C, 2000. Undersowing Italian ryegrass diminishes nitrogen leaching from spring barley. Agric. Food Sci. Finland. 9:201-15.

Lewan E, 1994. Effects of a catch crop on leaching of nitrogen from a sandy soil: simulations and measurements. Plant Soil. 166:137-52.

Mayer J, Buegger F, Jensen ES, 2003. Residual nitrogen contribution from grain legumes to succeeding wheat and rape and related microbial process. Plant Soil. 255:541-54.

Mechri M, Patil SB, Saidi W, Hajri R, Jarrahi T, Gharbi A, Jedidi N, 2016. Soil organic carbon and nitrogen status under fallow and cereal-legume species in a Tunisian semi-arid conditions. Eur. J. Earth Envir. 3:1-13.

Miedaner T, Schwegler DD, Wilde P, Reif J, 2014. Association between line per se and testcross performance for eight agronomic and quality traits in winter rye. Theor. Appl. Genet. 127:33-41.

Nemeikšiene D, Arlauskiene A, Šlepetiene A, 2010. Mineral nitrogen content in the soil and winter wheat productivity as influenced by the pre-crop grass species and their management. Žemdirbyste. 97:23-36.

Nykänen A, Salo T, Granstedt A, 2009. Simulated cereal nitrogen uptake and soil mineral nitrogen after clover-grass leys. Nutr. Cycl Agroecosys. 85:1-15.

Panagiotis D, 2015. Grain legume effects on soil nitrogen mineralization potential and wheat productivity in Mediterranean environment. Arch. Agron. Soil Sci. 61:461-73.

Petr J, 2005. Yield potential of rye, hybrid and population varieties in ecological and intensive cultivation. Sci. Agri. Bohem. 36:41-8.

Płaza A, 2011. Soil mineral nitrogen content after undersown catch crops in autumn and spring in the conventional and organic farming system. Fresen. Environ. Bull. 20:2446-50.

Płaza A, Makarewicz A, Gąsiorowska B, 2015. Influence of undersown catch crops on mineral nitrogen content determined in the soil profile in autumn and spring in conventional and organic farming system. Fresen. Environ. Bull. 10:3315-9.

Utomo VH, Sitompul SM, Noordwijk MV, 1992. Effects of leguminous cover on subsequent maize and soybean crop son an ultisol in Lampang. Agriviata. 15:44-53.

Sądej W, Przekwas K, 2008. Fluctuations of nitrogen levels in soil profile under conditions of a long-term fertilization experiment. Plant Soil Environ. 54:197-203.

Sanju UM, Singh BP, Whitchead WF, Wang S, 2007. Accumulation and crop uptake of soil mineral nitrogen as influenced by tillage, cover crops, and nitrogen fertilization. Agronomy J. 99:682-91.

Sarunaite L, Kadziuline Z, Deveikyte I, Kadziulis L, 2013. Effect of legume biological nitrogen on cereals yield and soil nitrogen budget in double-cropping system. J. Food Agric. Environ. 11:528-33.

Thorsted MD, Olsen JE, Weiner J, 2006. Mechanical control of clover improves nitrogen supply and growth of wheat in winter wheat/white clover intercropping. Eur. J. Agron. 24:149-55.

Tripolskaja L, Šidlauskas G, 2010. The influence of catch crops for green manure and straw on the infiltration of atmospheric precipitation and nitrogen leaching. Žemdirbyste. 97:83-92.

Watson CA, Atkinson D, Gosling P, Jackson LR, Rayns FW, 2006. Managing soil fertility in organic farming systems. Soil Use Manag. 18:239-47. 